\title{
BOUNDARIES FROM BORDERS: CROSS-BORDER RELATIONSHIPS IN THE CONTEXT OF THE MENTAL PERCEPTION OF A BORDERLINE - EXPERIENCES FROM SPANISH-FRENCH AND POLISH-GERMAN BORDER TWIN TOWNS
}

\author{
Iwona Markuszewska ${ }^{1}$, Minna TANSKanen², Josep Vila Subirós ${ }^{3}$ \\ ${ }^{1}$ Institute of Physical Geography and Environmental Planning, Adam Mickiewicz University in Poznań, Poland \\ ${ }^{2}$ Department of Geographical and Historical Studies, University of Eastern Finland, Joensuu, Finland \\ ${ }^{3}$ Environment Institute, Department of Geography, University of Girona, Spain
}

Manuscript received: January 21, 2016

Revised version: March 10, 2016

\begin{abstract}
MarkuszewsKa I., TansKanen M., Vila Subirós J., 2016. Boundaries from borders: Cross-border relationships in the context of the mental perception of a borderline - experiences from Spanish-French and Polish-German border twin towns. Quaestiones Geographicae 35(1), Bogucki Wydawnictwo Naukowe, Poznań, pp. 105-119, 1 fig., 1 table.
\end{abstract}

ABSTRACT: In this paper, the borderlands, in the context of the psychological perception of frontiers, were presented. The common relationships between different nationalities living in border twin towns was a principal point of analysis. During the investigation two main research questions were asked: Is a frontier a barrier or a bridge in the common relationships between nationalities living on both sides of the borderline? and Does the trans-border casual social integration stimulate openness to neighbours? The study was conducted in two double towns: La Jonquera (Els Límits) - Le Perthus at the Spanish-French border and Słubice - Frankfurt-am-Oder at the Polish-German border. The data were gathered from surveys by questioning locals and visitors during street polling. The design of the questionnaire included three main groups of questions relating to: 1) the perception of the borderline and the role of the border twin towns, 2) the attitude towards neighbours and identification with the borderlands, and 3) the future of the borderline in the context of the twin towns existence and cross-border linkages. The results showed that the historical circumstances and cultural background play a crucial role in the current bilateral interrelations between nations sharing the common space of the twin towns. These two aspects of the borderland have an influence on the psychological perception of the border that creates mental boundaries in local societies. However, as the results proved, the necessity of living together pushed locals to be more open-minded, which as a consequence supported the establishment of social bonds.

KEY WORDS: borderline,twin towns, neighbourhood, perception,cultural identity, Spanish/Catalan-French borderland, Polish-German borderland

Corresponding author: Iwona Markuszewska (iwmark@amu.edu.pl)

\section{Introduction}

A borderland is a specific area, where two or more political systems are intertwined with the existence of local residents which all influence the socio-economic sphere of bilateral relations. The geo-political structure thus created, imposes limitations on completely free and open social connections, but on the other hand, the close proximity of the neighbourhoods enforces less formal contacts between the different nationalities living on both sides of the borderline and is thus conducive 
to improving everyday life and common space. Additionally, a borderland is a unique phenomenon, where varied economic conditions encourage local enterprisers to be more competitive (Agnew 1994, Newman, Paasi 1998, Zimmerer 2007, Jones 2009, Newman 2010).

In the case of a borderland, twin towns take up a superior position in mutual relations between nationalities. Through history and the changing circumstances, locals were able to learn how to manage with the restrictions of the borderline and simultaneously reap the benefits of border proximity (Jańczak 2013).

The main aim of this paper is to present trans-border relationships between different nationalities living in twin towns in two diverse parts of Europe. Through analysis of the mental and social features of the borderline, such as: perception, attitude, cultural and national identity, a significant contribution to current borderland research was made. For research purposes, two border twin towns were selected: La Jonquera (Els Límits) - Le Perthus on the Spanish-French borderland and Słubice - Frankfurt-am-Oder on the Polish-German borderland. Worth noting is that these well-chosen borderlands are good examples in viewing how historical circumstances can influence the current mental perception of the borderline. The results proved that, in the time dimension, political control of the national border in the case of border's restrictions or openness, made a huge impact on the social attitude and evaluations of the neighbourhoods' interrelations between nationalities and ethnic groups living in the border regions.

In this paper the term 'borderline' was defined as a political construction which works under socio-cultural conditions which, as a consequence, create differences in the mental perceptions of the borderland. This approach, as a supplementary goal of the research, brings a new viewpoint to the discussion on borderlands.

\section{Theoretical background}

Bearing in mind the 'borderland' issue, in the context of the methodological framework adopted in this paper, some 'border' aspects must be clarified here. Firstly, the vital definitions and meanings of 'borderland' and 'border' will be presented. Afterwards, human perception of the borderland will be discussed with a view of the psychological and cultural barriers. Then, the attention will be focused on cultural identity as a process of creating cultural borders. Finally, the phenomenon of border twin towns will be shown in the context of bilateral relationships.

Borderlands represent a very curious point of research interest, not only from a geographical perspective, but also from historical and economic points of view. Because of this, borderland is a common inquiry subject of varied scientific disciplines, its definition is far from being uniform. Many researchers and scholars, who work on the 'borderland' terminology greatly contributed to extend the understanding of border issues. Bearing in mind the methodological framework of this paper, the most important criterion was the perceptual dimension, based on the subjective and emotional identification of the people with the border area, that is, the place where they live.

Brunet-Jailly (2011) declares that frontier territories and borderlands are the outcome of the interactions and intersections between people limited by a certain area. Rippl et al. (2010) add that for this reason border regions offer a unique opportunity for its inhabitants in the aspect of transnational social integration. Delhey (2005) explains that social integration in border areas mainly consists of transnational pairwise connections. As a good basis for 'European social integration', Delhey (2004) posits mutual solidarity, positive attitudes, and trust among the regional neighbours.

A border can be explained, in its simplest form, as a line on maps or barriers on the ground, whose existences are confirmed on many grounds: political, economic and social (Agnew 2008). However, in practice, borders are a complex phenomenon rather than a simple land division. Additionally, Newman and Paasi (1998) emphasize that, even if frontiers are more or less random lines between territorial units, usually they have deep symbolic, cultural, historical and religious meanings for social communities living on different sides of the borderline. For this reason, boundaries are very often laboratories of emotions, fears and memories that might be used for progressive or regressive purposes (Paasi 2009). 
State borders can be established following some geographical features, such as mountain ridges or riverbeds, and these are often called natural borders. Nowadays the significance of natural borders has decreased and the borderlines are more often cultural or political demarcations rather than physical boundaries. Nevertheless, natural boundaries can be very convenient for border management, as they are easier to cope with and control (Newman 2003). In contrast, political borders are traditionally seen as the borders separating states from each other. Some political borders are more closed than others, which, in practice means that they may prevent the movement of people or some specific commercial goods. Additionally, political borders can have a big impact on prices and welfare, which is observed in many border twin towns, where the difference of the political regimes has created a commercial zone. However, no matter what kind of borders we have in mind, the physical obstacles at the border have a huge impact on the human perception of the borderland (Williams 2003).

From the socio-cultural point of view, in daily lives, borders are manifested by inter alia: national identity, language, culture, myths, arts, history, heritage, politics, legislation and economy (Paasi 1996, Häkli 1999). This means that borders, which are sometimes regarded as psychological and cultural barriers, create differences between the people living on either side of the border, leading to the experiencing of otherness and separate identities (Newman 2003). Also, interesting to note is that borders between social groups, do not only separate geographical space, but also mostly constitute a linguistic barrier (Rippl et al. 2010).

As O'Dowd claims (2001), borders are essential to behaviour; they are the universal product of the need for order, security and belonging in human life. Boundaries express human desires for similarity and variety, for a differentiation between the 'known' and the 'unknown' and between 'us' and 'them'. Nonetheless, borders not only constitute social units, but also depend on the nature of the mutuality within the units, where the provision of mutual security and support reinforce already established boundaries (O'Dowd 2010).

Furthermore, landscape borders are a physical phenomenon differently perceived by people. Newman (2003) states that, even if there is no physical boundary, people can feel and perceive a border as a mental barrier. And in a contrast to this, a border can be ignored by people, if it is easy enough to cross it in their daily lives. This proves that a border can be a strong barrier which creates in people's minds a more powerful image of what is on the other side. Owing to this, people shape positive or negative perceptions of their neighbours (Newman 2003). Also, it is important to note that borders are resistant to change, and therefore in border studies it is fundamental to understand the perceptions and daily practices of the ordinary people living in the borderland areas (Newman 2010).

Borders, perceived as physical barriers dividing states and geographic space, are also considered as transformative and evolving processes roots in political, economic and social reasons (Xheneti et al. 2012). This process of border-territory changes, called 'de-bordering' (Newman 2006, Häkli 2008, Jańczak 2011), is one of the goals of European integration. However, the political and economic aspects of de-bordering are performed faster than the mental de-bordering process, and as a consequence, even if the geo-political borders between nationalities are disappearing, the mental and psychological barriers still exist and influence the mutual relationships of the local society ( $\mathrm{O}^{\prime}$ Dowd, Coakely 2007). Additionally, in the context of the current political situation in Europe, regarding the growing anxiety about immigration and terrorism, an increase of border security is observed, against the inflow of 'what is unwanted' in the opinion of politicians and citizens.

Also, national boundaries are favourable for the isolation of certain social groups, which reinforces the sense of territorial (national) identity. The collective identity puts its emphasis on the role of the distinction between 'us' and 'them', building in this way a social attitude to a boundary (Sahlins 1989, Pettman 1996, Donnan, Wilson 1999, Cooper, Perkins 2012). In this way boundaries do not reject the meaning of the border as a physical delimitation of state units, but present a connection between space and society (Paasi 1996). However, a borderland is distinguished not only by national identity, but also cultural distinctiveness. Häkli (1999) explains that national identity emphasises the belonging of a given group of people to a certain living area whereas cultural identity creates the people's sense 
of themselves and their common relations. In a wider meaning, cultural identity is defined as the identification of a group of people who share a common territory, ideas, normative system and language which distinguish ethnic groups from one another. Cultural identity is shaped through the influence of social institutions like the family, education system and mass media. On the other hand, living in a globalised world and being under constant culture exchange, modern cultural identities have reached a crisis point: modern society and its cultures are undergoing constant and rapid change (Hall 1996). Furthermore, cultural identity is also a meeting point of several cross-cultural implications, because the aspect of cultural identity involves the questioning of the self and of culture.

From another perspective, cultural identity is responsible for the establishing of cultural borders, manifesting themselves as different morals, values and ethics (Newman 2003). However, what makes the cultural borders imperative, is the protection against an infiltration of values which are not compatible with the hegemonic practices of the majority. For this reason, it may be very difficult to open these kind of borders as they are so deeply rooted in human minds.

Border regions are unique areas because borderlands provide the setting for the encounter and interaction of members of at least two different nationalities. Johnson (2009) points out that European border regions are a great incubating space for the establishment of cultural interactions and the development of economic grounds for neighbouring countries. In these regards, border twin towns can be an interesting example of trans-border experimentation.

Generally speaking, the term 'border twin towns' describes two towns located very close to a border, that is, near another urban unit on the other side (Dołzbłasz 2015), or one urban structure divided by a borderline (Jańczak 2013). Dołzbłasz (2015) mentions other alternative terms, describing this specific type of city construction, that appear in professional literature; double town, divided city, split town, sister towns, city-pairs, trans-border cities, bi-national towns, cross-border urban space and cross-border metropolises. Although, these terms can be used interchangeably, the meaning of them is slightly different and the subtle differences are relevant in the cases of certain twin towns. For example, as for the Spanish-French border towns we can say 'city-pairs', but regarding the PolishGerman case, 'divided city' or 'split town' are more accurate bearing in mind the fact that in the latter, after the WWII, the towns were divided by the borderline.

Despite the fact that border twin towns are faced with formal restrictions because of the different legal rules of both states, they have a great chance of establishing cross-border cooperation, in both economic and social fields. In many cases, the ambition of the double towns' government is to create one joint urban structure and the interest of the locals is to build friendly mutual relationships between the two nations on either side of the border. And it is exactly this attitude to border twin towns which is the key point of the research presented in this paper.

\section{Research design}

Borders can be studied from different viewpoints and within different kinds of frameworks: geographical, historical, economic, political, social and cultural. The results of the borderland studies presented in this paper were concentrated on socio-cultural approaches in relation to a geo-political context. The main research interest was focused on the following aspects: 1) the perception of the borderline and the role of the border twin towns, 2) the attitude towards neighbours and cultural identification with the borderland, and 3) the future of the borderline in the context of the twin towns existence and cross-border linkage.

Bearing in mind the specific field of interest, during the investigation, methods from a cultural-oriented geographical research area were taken into consideration. Most important was to get an insight of the variety of the opinions, views, sensations and feelings from local residents living in the borderlands as well as visitors coming to the border double town. Owing to this, street interviews were conducted. However, instead of closed-questions, which are more frequently used in this kind of research, here the questionnaires' framework consisted of open and semiopen questions (Table 1). This approach was more helpful to encourage interviewees to greater 
Table 1. Questionnaire's frame - a range of issues. Source: authors' elaboration.

\begin{tabular}{|l|l|}
\hline \multicolumn{1}{|c|}{ Area of Interest } & \multicolumn{1}{c|}{ Selected Detailed Questions } \\
\hline $\begin{array}{l}\text { The perception of the bor- } \\
\text { derline and the role of the } \\
\text { border twin towns }\end{array}$ & $\begin{array}{l}\text { How do you perceive the borderline? } \\
\text { Do you feel this area as a border? } \\
\text { What do you think the biggest change was after the opening of the border? } \\
\text { What are the advantages and disadvantages of the border opening? } \\
\text { For what purposes do you cross the border? }\end{array}$ \\
\hline $\begin{array}{l}\text { The attitude towards neigh- } \\
\text { bours and cultural identifi- } \\
\text { cation with the borderland }\end{array}$ & $\begin{array}{l}\text { What do you think about the location of your home town? } \\
\text { What do you feel about the twin towns you live in? } \\
\text { What does it mean to you to be Catalan/French, Polish/German and living in Els }\end{array}$ \\
& $\begin{array}{l}\text { Limits/La Pertus, Słubice/Frankfurt am Oder? } \\
\text { Do you identify with your home town or border region? } \\
\text { What does cultural identity mean to you? }\end{array}$ \\
& $\begin{array}{l}\text { How do you express your cultural/national identity? } \\
\text { Do you have any relations with inhabitants of the border town? } \\
\text { Are there any conflicts between different nationalities living on both sides of the } \\
\text { border? } \\
\text { Do you know the native language of your neighbour? } \\
\text { What do you think about the necessity of learning the neighbour's language and pre- } \\
\text { paring bilingual information about the border area? } \\
\text { How important is the integration of nations living on both sides of the border? }\end{array}$ \\
\hline $\begin{array}{l}\text { The future of the borderline } \\
\text { in a context of the exist- } \\
\text { ence of the twin towns and } \\
\text { cross-border links }\end{array}$ & $\begin{array}{l}\text { What do you think about the future of the border and border twin towns? } \\
\text { What do you think about the cooperation between the twin towns? } \\
\text { Do you think that cooperation between the two towns is important? }\end{array}$ \\
\hline
\end{tabular}

openness and freedom of speech. However, responses from open questions are almost impossible to analyse in a quantitative manner and therefore it was decided that a qualitative analysis on the basis of the given answers should be conducted. In this case the qualitative research was used to gather the information about mental perception of the borderland, by examining people's attitudes, behaviour and motivations.

The analysis is based on survey data gathered from representatives of different borders areas. On $13^{\text {th }}$ May of 2013 the research took place in La Jonquera (Els Límits) - Le Perthus, the border twin towns between Spain and France, and on $14^{\text {th }}$ May of 2014 - in the border region between Poland and Germany in the twin towns Stubice Frankfurt-am-Oder. It is worth mentioning here that Els Límits, which is in fact a part of the La Jonquera municipality, is the Spanish (Catalan) part of the double town Le Perthus. For this reason, the name of the border twin towns in the case of the Spanish-French borderline is La Jonquera (Els Límits) - Le Perthus. The location of the study research is presented in Fig. 1. In each case 30 people were interviewed. Direct opinions were collected in random chosen interviews. For this reason the answers came from: 1) citizens of different nationalities, 2) locals and newcomers,
3) people of different ages, where the age span ranged from 15 to 75 years, 4) female and male genders, with an equal share of each of them, 5) people representative of different social statuses, and 6) representatives of different professions. All interviews were recorded, but because of the diverse language environment, the original interviews were done in the native languages (Catalan, French, Polish and German) and translated into English afterwards.

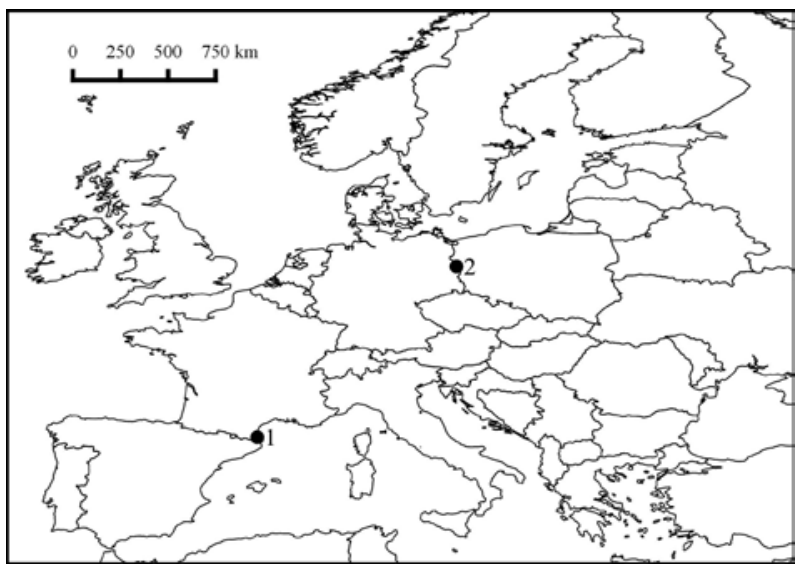

Fig. 1. Location of the study areas: 1 - La Jonquera (Els Límits) - Le Perthus on the Spanish-French borderland, 2 - Słubice - Frankfurt-am-Oder on the Polish-German borderland. Source: authors' elaboration. 


\section{The borderlines across countries - historical introspective}

All state borders have their histories, where different circumstances influenced their establishment. European countries have a long history of unsettled political borders (O'Dowd 2001). It is enough to mention the temporary politically unstable situations in the $20^{\text {th }}$ century and the setting of new borders after both World Wars as well as after the collapse of communism in the Eastern and Central European bloc of countries. Though, O'Dowd (2001) emphasises that, nowadays despite the fact that a lot of effort was put into coming up with the slogan 'Europe without Frontiers', in practice the process of European integration turned out to be one of managing an ever-increasing number of national frontiers. As a consequence, the enhancement of national borders will lead to a situation in which, rather than, 'Borderless Europe' we will say 'Europe of Borders'.

After the Second World War, it was understood that cooperation between European countries was needed to prevent new military conflicts. Owing to this, the European Coal and Steel Community was founded in 1951. Afterwards, the process towards a more integrated Europe led finally to the establishment of the European Union, guaranteeing the free movement of people across the associated countries. Steadily, the borders started losing their role as a barrier for humans and goods movement. Nevertheless, in Eastern Europe the process towards a more open international community started just after the collapse of the Soviet Union, at the beginning of the 1990 's. This event opened the possibility to create more friendly relations between neighbouring nations. One method in this direction could be the implementation of bilateral projects targeted to strengthen the cultural exchange across the borders to erase the mental borders (Brym 2011).

\section{The Spanish-French borderline}

The Spanish-French borderland was established after the Treaty of the Pyrenees in 1659, when Rosselló and the northern side of La Cerdanya became a part of France. An interesting fact is that since that time the borderline has never changed, so nowadays this border is one of the oldest and most stable in Europe. On the other hand, the establishment of the border, over 350 years ago, divided not only two countries: France and Spain, but also the uniform Catalan culture region, which can nowadays be found on both sides of the border. However, even if the Catalan language and culture has survived until today on the French side, it can only be seen in a very small minority and also without official recognition by the French state authorities. This is a result of the centralised hierarchy of French government that imposes the domination of the French language and culture on the whole country. On the other hand, in the Spanish part of the border, despite the extreme difficulties that the Catalan minority experienced in the past, the Catalan language and cultural heritage have survived. Nowadays, freedom of language is guaranteed by the Spanish Constitution that additionally, recognises the educational and cultural competences of the Generalitat of Catalonia (Catalan Autonomous Government), created in 1978 after the long period of Franco dictatorship and his fascist regime (1939-1975). Furthermore, nowadays the situation on the Spanish side is more complex, since Catalonia started the independence process, in 2012, confirmed by the last Catalan Autonomous election, in September 2015.

In recent history, a few milestones in the process of the Spanish-French border opening can be distinguished. The first significant step, during the decade of the $50^{\prime}$ s. of the $20^{\text {th }}$ century was a progressive normalization of the political and economical relations of the Franco regime with the rest of Western Europe in the framework of the Cold War. It played a fundamental role that the Spanish - French border became progressively more open and it helped the touristic and economic development of Spain. Since that time, La Jonquera and Els Límits has become a big custom centre for custom duty processing that has additionally improved the commercial relations between Spain and the rest of Europe. Through the $70^{\prime}$ s of $20^{\text {th }}$ century the customs services experienced a progressive increase, but it was the incorporation of Spain to the European Economic Community (EEC), in 1985, which was the main source of employment and economic prosperity of La Jonquera for the next three decades. 
Eventually, when the border between Spain and France disappeared, in 1993, when both of the countries became members of EEC, the important role of the customs duties became unnecessary. This had a strong negative economic impact on the twin towns, but especially the Spanish side which became embroiled in a deep economic and social crisis, the so called 'custom crisis'. Only the economic restructuring, started in the middle of the 90's, transformed this Spanish part of the border into a services zone. On the one hand, in La Jonquera a parking space for truck drivers was created, one of the largest in Europe, offering a wide range of services for the drivers. But, on the other hand, because of the fact that a thriving commercial area was developed mainly on the Spanish side of the twin towns (focused on French customers taking advantage of the lower taxes and purchasing goods with more competitive prices than in France), the French side of the double town fell into decline (Compte 1990, Lanao et al. 1990, Häkli 2002, 2004, Sanguin 2014).

It is important to note that nowadays, La Jonquera is not only a place where diverse goods can be purchased, such as: tobacco, alcohol, petrol as well as a wide range of clothes, food and perfumes, but also La Jonquera plays a really important role as a sexual services centre. One of the biggest brothels was located there under the Schengen agreement, partially implemented in 1995, which in fact allowed the establishment of large-scale legal prostitution zones in different borders areas of Europe (Sanguin 2015, Vicente et al. 2015).

\section{The Polish-German borderline}

The Polish German borderline was established after the Second World War. It is an example of one of the borders in Central and Eastern Europe, where borders cut historical and ethnic regions (Bufon 2007), which makes the borders unnatural and work against social relations. However, as Stokłosa (2012) claims, the Polish-German border shows how antagonism can be transformed into friendship.

After the Second World War, as a result of the Yalta and Potsdam conferences, the border between Poland and Germany was established on the Oder-Neisse line. As a result of this, both nations lost their eastern territories, which enforced a huge deportation (Ther 1998). Furthermore, because the border went along the rivers, the Oder and the Neisse, former German towns were forcibly partitioned, which resulted in the establishment of a number of divided towns, such as Zgorzelec-Görlitz, Gubin-Guben, SłubiceFrankfurt-am-Oder, Łęknica-Bad Muskau and many others (Jajeśniak-Quast, Stokłosa 2000, Jańczak 2011). Over the years the physical isolation led to a reinforcement of prejudices, and moreover, the closed border had a negative impact on trans-border relationships (Jańczak 2007).

The political climate during the post-war period made this border frozen: cross-border movements of people were prohibited, even though both East-Germany and Poland were parts of the Soviet bloc. The situation changed when the border was partly opened in 1971. This event was warmly welcomed by the locals and encouraged them to freely cross the border (Stokłosa 2008). Unfortunately, the rise of the Solidarność movement in Poland caused the re-closure of the border in 1980.

Visa-free travel between these two countries was forbidden, which had a negative influence, not only on the common relationships between ordinary citizens, but also had a negative repercussion on the development of common partnerships (Stokłosa 2008). Fortunately, many of the contacts were re-developed after the second opening of the border, in 1991. The early 1990's was a ground-breaking period for Eastern and Central European countries. The collapse of communism, the German reunification and the dissolution of the Warsaw Pact all brought the opening of the Polish-German border. The meaning of the border-crossing changed in 2004, when the accretion of Poland to the European Union not only established open borders, but strengthened the nature and level of cross-border cooperation (Stokłosa 2012). However, the definitive opening of the border made Słubice weaker, not only as a border crossing, but also as a place of business, because Słubice became less attractive for potential investors. 


\section{The perception of the borderline and the role of the border twin towns}

\section{The case of La Jonquera (Els Límits) - Le Perthus (the Spanish-French borderland)}

On the question of the influence of the border on local residents, the vast majority of respondents $(95 \%)$, of both Spanish and French nationalities, asserted that it is impossible not to feel like living on a border due to the continuous massive flow of goods and people moving through here every day. Also, due to the proximity of the border, interviewees drew attention to drug smuggling, which can be observed by locals in the enhanced police control (10 people).

When it came to the issue of the perception of the borderline with reference to the changes over time perspective, the majority of those surveyed $(83 \%)$ replied that the surroundings of the borderline had changed dramatically since the border was open in 1993. On the one hand, the change can be seen in the increasing rate of unemployment - many workers lost their jobs in the wood industry, because of the development of the commercial infrastructure. Consequently, a great number of native inhabitants moved away to other parts of Catalan or Spain. Nowadays more and more people coming into this area are just passing through or stay for a short while because of business reasons. On the other hand, the new construction of buildings and stores as well as the abandoning of the forest-cutting activities made the most imperative impact on land use in the surroundings of the twin towns, but especially La Jonquera. However, one response which kept repeating was that the greatest benefit of the opening of the border was the freedom of movement.

With regards to other benefits on the outcomes of the border opening, no clear answer can be seen. The interviewed people had mixed feelings about the issue of the border opening, which depended on the nationality or the profession and economic status of the individuals. For example, nowadays in the opinion of French traders, the economic situation is less favourable on the French side. They argue that business in
Le Perthus dropped due to the price differences between the French and Spanish sides of this twin towns. Because of this, many residents of Le Perthus became unemployment. However, some of the interviewed people ( 7 answers) expressed a positive attitude to the situation, because it forced them to reinvent themselves. Contrary to this, the youth expressed their satisfaction with these changes, because the development of the service sector offered them a wider brand of workplace. And obviously, opening the border contributed to the extremely dynamic economic growth of the Spanish side (Els Límits and the rest of La Jonquera municipality as well).

However, one of the disadvantages of the border opening, in the opinion of interviewees, was a rising feeling of insecurity as a result of less or a lack of police control in their previous fixed surveillance sites. Also another consequence of the disappearing strict police monitoring was that it allowed for easier drug smuggling, which seriously worried the local population. The surveyed locals unanimously agreed that the controls should be reinforced to improve the quality of living in the borderland.

As for visitors, the main reason for visiting Els Límits and the rest of the municipality of La Jonquera was shopping (95\% of responses). The customers are even the residents of the neighbouring Le Perthus, however, the low prices and diversity of products attract people from different regions of France. Frenchmen very often come to Els Límits to buy products because of lower prices than in many other towns in France. Besides, the diversity of products also allows customers to buy everything, from clothes and food, alcohol and cigarettes to furniture, all in one place. However, worthy of note here is that of these products, it is the perfumes and medicine, which make Els Límits the shopping destination for many Frenchmen. Nevertheless, these same reasons also attract Spanish visitors, because as Spanish interviewees said, the attractiveness of the prices encourages them to come here even if they have to travel a significant distance. Interesting is the fact that Catalan people very rarely visit the French town Le Perthus, and even more surprisingly, 5 of the interviewed people had never visited the French side at all. 


\section{The case of Słubice - Frankfurt-am-Oder (the Polish-German borderland)}

In the case of Słubice - Frankfurt-am-Oder, the borderline goes along the Odra River. Wherefore in the opinion of local residents, both German and Polish, the river is perceived as a natural landmark and a part of the landscape rather than a kind of the artificial border. But in the past, when the border was closed, the river itself was a limiting factor, which kept these two nationalities separated from each other - the majority of respondents (92\%) agreed on this point. Additionally, the border was strictly guarded and the checkpoints, located at the bridge, emphasized the existence of the border as a physical obstacle. But what is surprising currently is the fact that even if a physical limitation is practically non-existent, there is a strong mental barrier between the Poles and Germans, who, despite the fact that they live so close together, have such a profound prejudice against each other.

Bearing in mind the social and landscape changes after the border was opened at the beginning of the 1990's, a big transformation in the area near the borderline was observed. Most of the surveyed residents of both cities (one third) considered the occurring changes as positive, paying attention to the ease of border crossing. Yet, one of the disadvantages, on which the attention drew in particular German interviewees, was the rapid depopulation of Frankfurt, observed since the beginning of the 1990's. As a consequence, many abandoned blocks of flats were pulled down. On the other hand, the residents of Słubice emphasised that since the border crossing was facilitated and border checks removed, Słubice became more attractive for Poles from the neighbouring regions of Poland, who chose this town as a living place, and the German side of the borderland, but not only Frankfurt, as a working place. In both cases it is the financial reasons that explain this behaviour: German employers offer higher salaries, but living on the Polish side is less expensive. Eventually, these migratory movements rebuilt the urban structure of the twin towns: the Polish side is expanding, while the German one is shrinking. Nonetheless, almost all who were surveyed stated that the process of the border openness, and especially the Poland accession to the Schengen zone, decreased the role of the twin towns as a border-crossing, as it used to have in the past.

These days, the locals of the twin towns quite often cross the border and their freedom of movement has provided for the establishment of a special bus line. A large number of respondents (20 people) expressed their contentment, but this bus connection is especially useful for German customers coming to the Polish bazaar, which is located on the outskirts of Słubice. However, among the Polish retailers and owners of the shops in the city centre, a visible dissatisfaction with the bus line was observed. They argue that the direct bus line omits their shopping area, which in the past used to be a main destination for German customers.

The Poles interviewed were asked about their reasons for spending their free time in Frankfurt. Surprisingly, a half of them answered that they do not spend their free time there. In the group of those surveyed who gave a positive answer, the reasons for visiting the German side were the following; nice conditions for walking with children, cycling and other sports, going out with friends to pubs and restaurants. Also another reason was for the purchasing of some high quality German products, such as household chemical products. Generally, in the opinions of the surveyed Poles, the German side of the twin towns offers them better services. Additionally, for young Polish people, under the age of 25 , spending time in Frankfurt is more fascinating, because in Słubice there is a lack of certain kinds of social places, like for example, cinema or theatre, which they can find in Frankfurt.

On the opposite spectrum, the interviewed Germans spend their time in Słubice for several different aims. The most frequent reasons for visiting Słubice were; doing shopping, going to the hairdresser. refuelling the car and going out for a meal. As for shopping, the most commonly purchased goods are: bakery products and cigarettes. Obviously, the reasons for doing shopping and buying the aforementioned products are the lower prices and good service. 


\section{The attitudes towards neighbours and cultural identification with the borderland}

\section{The case of La Jonquera (Els Límits) - Le Perthus (the Spanish-French borderland)}

Because of the specific role of Els Límits - Le Perthus as a shopping area, the twin towns are visited by a high number of customers every day. For this reason, visitors represent a significant percentage of the respondents. Consequently, in the following section, firstly, the relationships between locals are presented and after that, the attitude to locals as expressed by the visitors.

With relation to the every-day-life of the local residents, all those who were interviewed stated that no barriers between both nationalities can be seen. As one of the residents of El Pertús said: For us, who live here, there have never been two foreign countries; we are a family and we have never existed like on at state border. This is clearly a result of a long and stable border persistence and the relative openness of the border over time.

None of the interviewees, neither the Catalans nor the French, are in any conflicts with each other and the common relationships are judged neutral or even friendly. Only the language issue was a matter of minor complaint: Catalans claimed that when they visit the French side, speaking French is a must. But it does not work conversely when French people visit Catalan side: Frenchmen do not need to speak neither Catalan nor Spanish. Wherefore, most of the questioned Catalans (93\%) knew French, at least at a basic level. This group was represented by young people under 30 , who find language skills important in improving their future and also helpful in their travelling experiences. In comparison, only a few of the interviewed Frenchmen ( 3 people) were able to prove themselves a knowledge of their neighbour's language. As one French respondent surveyed stated, he does not identify with Catalan culture and does not see the need to learn the Catalan language.

On the other hand, half of the visiting French respondents, who visited Els Límits - Le Perthus said that they have only business relations with Catalans, however, they have a positive attitude and good relationships with the locals. Some of those surveyed have friendly and cordial relations with the Catalan citizens of Els Límits. Only one French respondent expressed his doubts saying: sometimes it's difficult to trust, when we do not know each other. But this kind of misgiving is nothing surprising when we talk about general opinions about strangers.

As for the Catalans visitors to the twin towns, they admitted that their reason for visiting Els Límits - Le Perthus was shopping or other business purposes. Similar to the previous situation, both the locals and visitors, have harmonious relations with each other; whereas they tolerate each other, they do not get into closer relationships. This level of mutual involvement is typical for borderlands. However, among the Catalans interviewed there was one teenager, who would have a close personal relation with French living in Le Perthus.

In the case of cultural identity, none of the French respondents questioned expressed their national identity by using national symbols, explaining that there is no need to signify their emotions in this way. On the other hand, all Catalans openly expressed their national and cultural identity by displaying Catalan flags and wearing Barcelona T-shirts and other symbols of Catalan identity.

\section{The case of Słubice - Frankfurt-am-Oder (the Polish-German borderland)}

The survey results indicate that the close proximity of the Poles and Germans leads locals to involuntary integration, which helps to break down deep-seated prejudices towards their neighbours. For example, in the minds of Słubice's inhabitants, their German neighbours are not significantly differ from them. Moreover, they reported that the inhabitants of Frankfurt are good customers, which means a lot in a place where trade is very important for both sides of the border.

As for the surveyed Germans, half of them had relations with the inhabitants of Słubice like classmates or friends. No particular dislikes about Poles were observed; in the opinion of Germans, Polish people are friendly and as one noted: Polish people are more open-minded. I have better relations with them rather than Germans.

Also quite surprising are the opinions of the inhabitants of Słubice about their border identity 
as well as the identity of this special place of living. The majority of respondents $(97 \%)$ did not identify themselves either with Słubice, nor with this trans-border region. The only thing that distinguishes this border region from others, in the opinion of the interviewees, is the natural possibility for meeting foreigners, which automatically forces them to use foreign languages in everyday life. The biggest cultural benefit of this is learning to be more tolerant, stressed the respondents. Also, the border location of Słubice does not have any effect on cultural identity, according to the interviewed Poles. To be more precise, Polish culture does not mix with the German and the German culture has no influence on the Polish one, as the surveyed concluded.

Referring to the meaning of living in the German part of the twin towns, the interviewed inhabitants of Frankfurt expressed very positive feelings: they like living here and are happy because of this. Most of them can identify with Frankfurt and the border region as well. What is interesting is that, young people, under 25, more appreciated the relationships between the German and the Polish people, whereas the people older than 25 appreciated more the local culture and the city itself as a border town. The interviewed Germans admitted that the local cultural identities of both nations infiltrate mutually and influence life in both cities. Additionally, they emphasised that the proximity to Poland has a great importance in their lives. Furthermore, they claimed that in the language and culture differences they can see no obstacles in bilateral interaction, but actually the chance to raise the curiosity to get to know each other better.

As for the language issue, because of their connections with their German neighbours, all the Polish interviewees indicated that they had learned at least enough of the German language to be able to communicate. On the other hand, German interviewees could not say that they had even basic knowledge of Polish, but they admitted that they did know some Polish words and expressions. Nonetheless, everyone expressed their willingness to learn the Polish language, if such a possibility emerged.

\section{The future of the borderline in the context of the twin towns existence and cross-border linkage}

\section{The case of La Jonquera (Els Límits) - Le Perthus (the Spanish-French borderland)}

As for the future of the borderline and the twin towns, due to both, global and local economic situation fluctuation, the interviewed people are rather pessimistic, expressing their dissatisfaction or disillusionment with politicians and their decisions. Both nationalities, but especially Catalan, are pessimistic in the face of a future with the possibility of the increasing prices of key products like tobacco and alcohol, because nowadays the VAT difference between Spain and France makes the situation more favourable for Spanish. All interviewees were concerned about it and speculated what would happen if the prices of goods were equalized. This would be a huge loss of customers, perhaps even a shutting down of the La Jonquera commercial zone, as some of the interviewees stated. One of the surveyed Catalan retails said: It would cause a disaster here. La Jonquera, Els Limits would be removed from the map, because $90 \%$ of the customers are French and they come here for shopping to save money. There are many of them who come here from remote regions, like Marseille, to buy cheaper tobacco, alcohol and petrol. Unfortunately, in the context of future forecasts on the reductions of carbon dioxide emission and the introduction of a new transport system, it is probable that La Jonquera will lose its importance as a transportation zone in the meaning that it currently holds.

At a political level of common relationships, the authorities of both twin towns, Els Límits - Le Perthus are involved in promotion of the towns by organising a wide variety of cultural activities, in which locals participated together with their associations. Interesting here, is the fact that the common Catalan cultural background, on both sides of the borderline, is helpful in creating an openness of both nationalities and developing a common border identity. 


\section{The case of Słubice - Frankfurt-am-Oder (the Polish-German borderland)}

In the case of Słubice and Frankfurt-am-Oder, in the context of future changes, the opinions of interviewees are more optimistic than in the above case. However, there are some voices of doubt about the future economic situation connected with the possible implementation of Poland in the euro currency. This dissatisfaction is observed in both Germans and Poles because for both nations it would be harmful.

The intention of the local governments of both cities, is to establish one urban organism - a double town, but as for now, the border towns are connected with many joint projects and initiatives. Nonetheless, in the respect of common cooperation, there were some voices of doubt. Despite the desire to create joint projects and even implement them, several of the respondents said that the cities will never create one urban organism. Besides, responsers showed that Poles and Germans are mentally very different from each other and additionally, the disparity in the economic conditions between these twin towns is another obstacle.

Local residents expressed their belief that in the near future, cooperation will increase common relations. It shows the positive feelings of all interviewed on mutual projects leading to improvements the integration of the inhabitants of Frankfurt-am-Oder and Słubice. For example, the surveyed teenagers are keen on participating in every project, such as: common trips, meetings, teamwork and other activities, which are organised by the schools they attend. Students are willing to organise mutual ventures and implement different bilateral projects. Elderly people, like pensioners, are also open to participate in multi-cultural activities.

Among the Germans interviewed, opinions regarding the cooperation between Frankfurt and Słubice are positive. All those interviewed stated that such an effort is good in the integration process. However, the surveyed people did admit that their knowledge about the types of common activities is limited. Though, in their opinion, the level of common cooperation is not enough and some other activities should surely be conducted. An example of this could be the bilingual kindergarten located in Słubice. All of the interviewed
Poles knew about this investment, while only a few Germans knew about the project, however, they found the concept highly significant. They claimed that the integration of the German and Polish people on both sides of the Oder is important and it is something which should be taken as ordinary, bearing in mind the twisted history of both nationalities.

\section{Concluding discussion}

The results of the study on the borderland issues presented in this paper, gave a unique possibility to compare cross-border social relations between two towns divided by a borderline. The collected data delivered a lot of informative and also thought-provoking facts on social relationships across a border: the people's border identity, their perception of the borderland and the neighbouring nations as well as trans-border interactions.

Also, the results revealed the importance of historical and political factors in creating a cultural background and common attitudes to nations living on both sides of the frontier. The chosen twin towns represent extremely diverse cases of borderland connections: La Jonquera (Els Límits) - Le Perthus is created on the same socio-cultural roots, whereas Słubice and Frankfurt-am-Oder were established on 'unfriendly' ground.

As for the case of the Polish-German attitude and the cultural barriers resulting from tumultuous history, a piece of research conducted on this topic shows how this troublesome barrier impedes the building of friendly neighbouring relations (Krätke 1998, Bürkner 2001, Matthiesen et al. 2002, Jańczak 2007, Stokłosa 2008, Wilkinson 2009). However, as the study proved, the mental barriers between the residents of Słubice Frankfurt-am-Oder are losing their significance. The prejudices and stereotypes and negative perceptions of the neighbours are being overcome: in the survey the citizens of both towns emphasised that they do not want to live next to another, but rather, together and with each other. Besides this, the investigation proved that the attitude to borderland phenomena depends on personal perception of the border. For this reason, perception has multidimensional viewpoints reliant on subjective experiences and interpretations. 
Worthy of mention here, is that in the case of borderland identity, the inhabitants of the twin towns identify themselves not with the whole town, but the part in which they live (see similar results in Opiłowska 2011). But again, as was proved, the expression of identity depends on personal mentality. Hopefully, in the future when border cooperation continues, a different kind of common border identity might be born. Local residents have an awareness that overcoming communication obstacles by, for example, learning their neighbours languages is a necessary task in a border region. It helps them to get to know each other better, to interact and to grow together. This is especially crucial for future generations in an inner-European border region.

On the basis of the survey results, it might be concluded that according to the locals, in some aspects, the twin towns are very well mixed and connected together, but in other aspects - still separate from each other. Nonetheless, the general impression gathered from both studies convincingly shows that mutual cooperation will produce cultural benefits and improve communication across the border. In fact, this kind of close neighbouring can lead to involuntary integration, because the daily routine at the borderland encourages people to me more resourceful.

Additionally, it cannot be forgotten that some separating aspects of mutual collaborations existed, namely administrative and legal barriers. Even if the mental barriers are removed, obstacles can still be observed that have their roots in the legal differences between the two bordering towns. Effective cross-border co-ordination in the process of decision-making should be ensured, like for example, the drafting of common land-use plans and urban development projects. Furthermore, for better cooperation of the neighbouring regions, the twin towns should be merged economically. As the results show, the economical imbalance between Frankfurt-amOder and Słubice makes the latter less attractive and less competitive. Economic equality generates cross-border interaction and collaborations that stimulate the development of both markets.

Finally, the surprising fact is that in the opinion of the local society the state boundaries will not disappear in the near future. The roots of a kind of thinking like that is the conviction that borders ensure a feeling of autonomy and self-direction (O'Dowd 2010) as well as the belief that people are connected with a certain territory which creates their sense of place (Häkli 2008). Furthermore, bearing in mind the current political situation in Europe: the waves of external immigration and the threat of terrorism, the sense of safety has an increasing role in enhancing state border security. A good example of this new scenario is the introduction of strict security controls in the Spanish - French border after the terrorist attacks in Paris in November 2015. Obviously, all those who were surveyed are aware that the borders will transform into more flexible and fuzzy features, but undoubtedly, the boundaries will still be perceptible.

The conclusion that can be drawn from these facts is that in every situation political borders can create mental boundaries and all borders may be barriers and bridges at the same time. But as it was once said: some people have an interest in preserving the borders, whilst the others want to develop their bridging roles.

\section{Acknowledgements}

This article includes results generated from the project of the LLP-Erasmus Programme: Borderland: Border Landscape Across Europe, 2013-2014-1-FI1ERA 10-12960. We would like to thank all the students for participating in these two editions of the Intensive Programme. Special thanks go for PhD Roser Pastor for her supervision on the context of the Catalan-French relationships.

\section{References}

Agnew J., 1994. The territorial trap: the geographical assumptions of international relations theory. Review of International Political Economy 1(1): 53-80.

Agnew J., 2008. Borders on the mind: re-framing border thinking. Ethics \& Global Politics 1(4): 175-191.

Brunet-Jailly E., 2011. Special Section: Borders, Borderlands and Theory: An Introduction. Geopolitics 16(1): 1-6.

Brym M., 2011. The Integration of European Borders: A Case Study of Polish Opinions on Cross-Border Cooperation across a Fading German-Polish Political Border. University College of the Fraser Valley Research Review 3(3): 15-33.

Bufon M., 2007. Border Regions in a re-integrated Europe. Moravian Geographical Reports 15(1): 2-13.

Compte A., 1990. La Jonquera. Quaderns de la revista de Girona 96.

Cooper A., Perkins Ch., 2012. Borders and status-functions: An institutional approach to the study of borders. European Journal of Social Theory 15(1): 55-71. 
Delhey J., 2004. European Social Integration. From Convergence of Countries to Transnational Relations between Peoples. Social Science Research Center Berlin (WZB), Discussion Paper No. SP I 2004-201.

Delhey J., 2005. Das Abenteuer der Europäisierung. Überlegungen zu einem soziologischen Begriff europäischer Integration und zur Stellung der Soziologie zu den Integration Studies. Soziologie 34(1): 7-27.

Dołzbłasz S., 2015. Symmetry or asymmetry? Cross-border openness of service providers in Polish-Czech and Polish-German border towns. Moravian Geographical Reports 23(1): 2-12.

Donnan H., Wilson T.M., 1999. Borders: Frontiers of Identity, Nation and State. Oxford University Press, Oxford.

Häkli J., 1999. Cultures of Demarcation: Territory and National Identity in Finland. In: Guntram H., Kaplan D. (eds), Nested identities: Identity, Territory, and Scale. Rowman \& Littlefield, Lanham: 123-149.

Häkli J., 2002. Transboundary networking in Catalonia. In: Kaplan D., Häkli J. (eds), Boundaries and Place: European Borderlands in Geographical Context. Rowman \& Littlefield, Lanham: 70-92.

Häkli J., 2004. Governing the mountains: cross-border regionalization in Catalonia. In: Kramsch O., Hooper B. (eds), Cross-Border Governance in the European Union. Routledge, London: pp. 56-69.

Häkli J., 2008. Re-bordering spaces: The nation-state and the legacy of border studies. In: Cox K., Low M., Robinson J. (eds), The SAGE handbook of political geography. Sage Publishing, London: 471-482.

Hall S., 1996. Introduction: who needs identity?. In: Hall S., Du Gay P. (eds), Questions of Cultural Identity. Sage Publishing, London: 1-17.

Jajeśniak-Quast D., Stokłosa K., 2000. Geteilte Städte an Oder und Neiße. Frankfurt (Oder)-Słubice, Guben - Gubin und Görlitz - Zgorzelec 1945-1995. Berlin Verlag Arno Spitz GmbH, Berlin.

Jańczak J., 2007. Europeanization of Trans-border Communities. The Polish-German Case. In: Jańczak J. (eds), Redescovering Europe: Political Challenges in the $21^{\text {st }}$ Century EU. Wydawnictwo Naukowe INPiD UAM, Poznań: 77-88.

Jańczak J., 2011. Cross-border Governance in Central European Border Twin Towns. Between De-bordering and Re-bordering. In: Jańczak J. (eds), De-bordering, Re-bordering and Symbols on the European Boundaries. Logos Verlag, Berlin: 37-52.

Jańczak J., 2013. Revised boundaries and re-frontierization. Border twin towns in Central Europe. Revue d'études comparatives Est-Ouest 44(4): 53-92.

Johnson C., 2009. Cross-border regions and territorial restructuring in central Europe room for more transboundary SPACE. European Urban and Regional Studies 16(2): 177-191.

Jones R., 2009. Categories, borders and boundaries. Progress in Human Geography 33(2): 174-189.

Krätke S., 1998. Regional Integration or Fragmentation? The German-Polish Border Region in a New Europe. Regional Studies 33(7): 631-641.

Lanao P., Torns M., Vinyoles C., 1990. La mort de la frontera amaneça la Jonquera i Portbou. Revista de Girona 140: 22-28.

Matthiesen U., Bürkner H., 2001. Antagonistic structures in border areas: Local milieux and local politics in the Polish - German twin city Gubin/Guben. GeoJournal 54(1): 43-50.
Meinhof U., Galasiński D., 2002. Reconfiguring East-West identities: Cross - Generational discourses in German and Polish border communities. Journal of Ethnic and Migration Studies 28(1): 63-82.

Newman D., 2003. On borders and power: A theoretical framework. Journal of Borderlands Studies 18(1): 13-25.

Newman D., 2006. The lines that continue to separate us: Borders in a 'borderless' world. Progress in Human Geography 30(1): 143-161.

Newman D., 2010. Territory, Compartments and Borders: Avoiding the Trap of the Territorial Trap. Geopolitics 15: 773-778.

Newman D., Paasi A., 1998. Fences and neighbours in the postmodern world: boundary narratives in political geography. Progress in Human Geography 22(2): 186-207.

O'Dowd L., 2001. State Borders, Border Regions and the Construction of European Identity. In: Kohli M., Novak M. (eds), Will Europe Work? Integration, employment and the social order. Routledge, London: pp. 95-110.

O'Dowd L., 2010. From a 'borderless world' to a 'world of borders': bringing history back in. Environment and Planning, D: Society and Space 28(6): 1031-1050.

O'Dowd L., Coakely J., 2007. The Transformation of the Irish Border. Political Geography 26(8): 877-885.

Opiłowska E., 2011. Grenze im Verschwinden? Deutsch-polnische regionale und grenzüberschreitende Zusammenarbeit. In: Bingen D., Loew P., Ruchniewicz K. Zybura M. (eds), Erwachsene Nachbarschaft. Die deutsch-polnischen Beziehungen 1991 bis 2011. Harrassowitz Verlag, Wiesbaden: 269-279.

Paasi A., 1996. Territories, Boundaries and Consciousness: The Changing Geographies of the Finnish-Russian Border. Wiley, Chichester.

Paasi A., 2009. The resurgence of the 'Region' and 'Regional Identity': theoretical perspectives and empirical observations on regional dynamics in Europe. Review of International Studies 35(S1): 121-146.

Pettman J.J., 1996. Border crossings/shifting identities: minorities, gender, and the state in international perspective. In: Shapiro M., Alker H.R. (eds), Challenging Boundaries: Global Flows, Territorial Identities. University of Minnesota Press, Minneapolis: pp. 261-284.

Rippl S., Bücker N., Petrat A., Boehnke K., 2010. Crossing the Frontier Transnational Social Integration in the EU's Border Regions. International Journal of Comparative Sociology 51(1-2): 5-31.

Sahlins P., 1989. Boundaries: The Making of France and Spain in the Pyrenees. University of California Press, Berkeley.

Sanguin A.L., 2014. The Schengen effects at the EU's inner borders: cheaper stores and large-scales legal prostitution: the case of the La Jonquera area (Catalonia - Spain). In: Bufon M., Minghi J., Paasi A. (eds), The new European frontiers: social and spatial (re)integration issues in multicultural and border regions. Cambridge Scholar Publishing, Cambridge: 196-207.

Sanguin A.L., 2015. Paisagens de fronteira: variaçoes em um importante tema da geografia política. Boletim Gaúcho de Geografia 42(2): 389-411.

Stokłosa K., 2008. VR Polen und die DDR: Die Bedeutung der Grenze für das 'Freundschaftstheater'. In Partner oder Kontrahenten? In: Schmeitzner, M., Stokłosa, K. (eds), Deutsch-polnische Nachbarschaft im Jahrhundert der Diktaturen. Berlin: LIT Verlag. (pp. 193-203).

Stokłosa K., 2012. Neighborhood Relations on the Polish Borders: The Example of the Polish Borders: The Example 
of the Polish-German, Polish-Ukrainian and Polish-Russian Border Regions. Journal of Borderlands Studies 27(3): 245-255.

Ther P., 1998. Deutsche und polnische Vertriebene. Gesellschaft und Vertriebenenpolitik in der SBZ/DDR und in Polen 1945-1956. Vandenhoeck \& Ruprecht, Göttingen.

Vicente J., Pastor R., Martín J., Villanova J.L., 2015. Borders and Boundaries of Catalonia. Present and Future in a New State's Scenario. In: Brańka T., Jańczak J. (eds), Boundaries revisited. A conceptual turn in European border practices. Logos Verlag, Berlin: 113-124.

Wilkinson J., 2009. Die härteste Sprachgrenze Europas? Negotiating the linguistic divide in theatres on the German-Polish border. In: Carl L., Stevenson P. (eds), Lan- guage, discourse and identity in central Europe: The German language in a multilingual space. Palgrave Macmillan, London: 73-95.

Williams J., 2003. Territorial borders, international ethics and geography: do good fences still make good neighbours? Geopolitics 8(2): 25-46.

Xheneti M., Samallbone D., Welter F., 2012. EU enlargement effects on cross-border informal entrepreneurial activities. European Urban and Regional Studies 20(3): 314-328.

Zimmerer K.S., 2007. Cultural ecology (and political ecology) in the 'environmental borderlands': exploring the expanded connectivities within geography. Progress in Human Geography 31(2): 227-244. 